\title{
REMOTE LEARNING IMPLEMENTED BY BIPA TEACHERS DURING COVID-19 PANDEMIC
}

\author{
Tri Indri Hardini ${ }^{1}$, Sri Setyarini ${ }^{2}$, and Sri Harto ${ }^{2}$ \\ ${ }^{1}$ Department of French Education Universitas Pendidikan Indonesia, Indonesia \\ ${ }^{2}$ Department of English Education Universitas Pendidikan Indonesia, Indonesia \\ email: tihardini@upi.edu
}

\begin{abstract}
This research aimed to describe how BIPA teachers implemented remote learning process, identify the problems encountered during COVID-19 pandemic, and explore how Indonesian cultural elements were introduced to students of primary and secondary schools. This research applied a case study design involving eight BIPA teachers in Victoria, Australia as participants. The data were collected through survey questionnaire, virtual interviews, and document analysis. The research data were analysed by making data categories regarding the implementation of remote learning, identification of its problems, and the introduction of Indonesian cultures to students. Interpretation of research findings was done by using relevant theoretical framework. The research findings indicated that the BIPA teachers implemented the remote learning through providing a learning model, listening to students' individual reading practices, doing a discussion with the students, and implementing simple practices on the selected materials. One of the problems encountered was about students' motivation. The elements of Indonesian cultures were introduced through identifying its types, describing the identified types of cultures, and writing short essays on the selected cultural topics.
\end{abstract}

Keywords: BIPA teachers, COVID-19 pandemic, remote learning

\section{INTRODUCTION}

The phenomenon of COVID-19 pandemic has impacted every sector of human life including education. Teachers and students are key players in the implementation of education at schools. During this challenging and difficult time, the teachers should think how they run classes so that the students can study well. For this reason, the government of each country in the world has to make relevant policies to run classes through the use of technology. Various learning platforms using the modes of both synchronous and asynchronous are used by the teachers and students to implement their teaching and learning processes. During the COVID-19 pandemic, the implementation of education is usually done through online learning which is popularly known as remote learning (Hooker, 2020; Nielsen, 2020; Ofgang, 2020; Ray, 2020a \& 2020b).

More than 1.5 billion students in 165 countries (UNESCO, 2020) in the world are affected by the COVID-19 pandemic. In order to make sure that, the students do not stop learning, teachers and students change their learning system from offline to remote learning or online. The remote learning is done by the teachers to ensure that the students can virtually meet the teachers during the process of learning when they are actually learning and teaching from different areas of origin through virtual classes. 
During the COVID-19 pandemic, Australia as one of the Indonesia's neighbouring countries is implementing the teaching of Indonesian for the students in Victorian schools. The teaching of the Indonesian for foreign speakers, in this particular context is for Victorian students, popularly known as Bahasa Indonesia bagi Penutur Asing (BIPA). In addition to Australia, BIPA is now growing very rapidly and it has even been popular in some countries in the world (Hardini et al., 2019, p. 331). The popularity of the language is reasonable since in the South East Asian (ASEAN) region, for instance, Indonesian has shown the highest number of speakers (Wurianto, 2015). This condition opens the chance to attract learners from the ASEAN and even from the other regions in the world. The success of the Indonesian learners overseas would improve the existence of the Indonesian (Setyawan et al., 2017).

The BIPA learning program should empower learners to obtain Indonesian competence supported by a stronger cultural knowledge. It means that the students who are learning the Indonesian are expected to use the language correctly in different learning contexts. The focus of learning is not only in the aspect of grammar but also in the aspect of other language skills, such as listening, speaking, reading and writing. It means that in the process of learning, language learners should not only be provided with grammatical knowledge, but they are also enhanced with the cultural knowledge to minimize a cultural shock (Yusari, 2012). The Indonesian cultural knowledge in the BIPA learning, for instance, is introduced to provide students with some comprehensive understanding about Indonesia. Therefore, in addition to the mastery of Indonesian competence, Indonesian learners should be encouraged to actively engaged in Indonesian cultural empowerment through various activities to comprehensively understand the language and its cultures.

As the consequence, the BIPA teachers were required to demonstrate their competences through the practices of quality learning. In order to achieve a quality learning, the BIPA teachers have to determine the learning objectives, select adequate learning materials, implement relevant teaching methods, and create appropriate learning media to result in optimum learning achievement. The students' learning achievement can be identified by some factors, such as teachers, students, learning strategies, and learning materials (Mana et al., 2020, p. 154). In addition, the students' learning achievement can also be viewed from their learning media and motivation (Hartoyo, 2009, p. 68). To achieve success in the teaching and learning process, Majid (2013) has also reiterated that teachers have to motivate students to learn and to communicate with them. In this condition, students can engage with a variety of asynchronous learning contents in their selected schedules (Sinha \& Basu, 2020). However, in this difficult time they have to catch up the mastery of technologies used for BIPA learning process virtually organized during the COVID-19 pandemic (Istanti, 2020; Zhang et al., 2020) since the virtual media are the ones to be the main media for running the learning programs.

To answer questions on the implementation of remote learning, identification of problems encountered during the COVID-19 pandemic, and the introduction of Indonesian cultural elements to foreign students would not be easy for the BIPA teachers. Therefore, this particular research topic is worth researching to provide the BIPA teachers and students with specific 
teaching and learning experiences in this difficult time.

\section{METHOD}

This research applied a qualitative method with a case study design. Eight BIPA teachers (Ts: T1, T2, T3, T4, T5, T6, T7, \& T8) consisting of one male and seven females were purposively recruited to participate in this research. They were undertaking their works as BIPA teachers in different Victorian schools from primary to secondary levels. One group of the BIPA teachers in service during this COVID-19 pandemic were the teachers of Indonesian graduated from Universitas Pendidikan Indonesia (UPI) majoring in Indonesian education and English language education. Their participation in this program was managed on the basis of collaborative activities between three parties, the Department of Education and Training (DET), Victoria, Australia, Monash University, Australia and UPI, Bandung, Indonesia based on the Memorandum of Understanding (MoU, 2004, 2010), and then it was extended for the following years between DET and UPI (MoU, 2017) on the provision of the BIPA teachers graduated from UPI to work in Victorian schools, Australia fully funded by DET for approximately one year. In this particular group, they started working as BIPA teachers in January 2020 and they were scheduled to complete their duty in December 2020.

The data were collected through a survey questionnaire (Quest), virtual interview (Virt-Int) via zoom meeting, and document analysis (Docs) (Hancock \& Algozzine, 2006; Malik \& Hamied, 2016). The survey questionnaire was administered using semi-structured questions to investigate the data about the learning activities applied during the COVID-19 pandemic and identify the learning platforms used by the BIPA teachers in the implementation of remote learning. The virtual interviews were done via zoom meetings using open-ended questions to explore the BIPA teachers' experiences to introduce the Indonesian cultural elements to the students. The interviews were also meant to confirm some data obtained from the survey questionnaire and complete the missing information needed to answer the research questions. The survey questionnaire was written in an Indonesian and the interviews were also done in the Indonesian in order to provide the BIPA teachers as participants of this study with clear instructions and better understanding on the questions raised to them. Then, relevant documents such as curriculum, lesson plans, and samples of learning materials were also used to support the data that have been obtained both from the survey questionnaire and from the virtual interviews.

Data of the research obtained from the survey questionnaire were then selected and classified into some categories based on the patterns of data and the relationships among the related variables. The results of the interviews were then transcribed and coded to classify them into several categories on the basis of the BIPA teachers' practices in the implementation of remote learning. The process of codification was also meant to reduce irrelevant data in order to obtain the selected details and clear, informative, and valid data (Creswell, 2012) and to arrive in trustworthy data to answer the research questions. The process of interpretation of data was done through comparing and contrasting the data with theories of remote learning implemented by some experts during the COVID-19 pandemic. Description and association among the data were systematically and logically 
organized meant to use them as the basis for synthesizing and analyzing the research findings to draw some conclusions.

\section{FINDINGS AND DISCUSSION}

Results of this research are purposively presented based on the common categories of data including the implementation of remote learning applied by BIPA teachers, typical problems encountered by both the teachers and students, ways out taken by the BIPA teachers to solve the problems, and the presentation of the Indonesian cultural elements introduced by BIPA teachers to the students.

With regard to the main activities implemented by the BIPA teachers in the remote learning, the relevant information is provided in Table 1 to describe the school level, targeted skills, and the main activities done by the BIPA teachers (Ts) in Victoria, Australia (Virt-Int \& Quest (T1-T8) \& Docs (OIER, 2011-2019). The school covered primary and secondary school levels spread out in different areas and locations within Victoria, Australia. The targeted skills for these school levels included four language skills, such as reading, writing, listening, speaking, and grammar. The main activities included the activities which referred to the elaboration of the targeted skills from reading, writing, listening, speaking, and grammar. The identified main activities included the activities of reading texts in different topics with regard to the Indonesian cultures, writing sentences using specific terminologies, writing short paragraphs using certain grammatical rules, writing short texts using topics in their own interests, listening to teachers' stories and videos in the contexts and topics of discussion, speaking through answering teachers' questions, retelling materials that have been learned and retelling other stories in the contexts and topics of interests. The descriptions of the main activities are briefly written in Table 1 .

Based on Table 1, in the process of teaching and learning, for instance a BIPA teacher-8 (T8) taught a reading skill using a descriptive text entitled "Indonesian Transportation". This activity aimed to develop students' knowledge on the contexts and types of transportation in Indonesia, particularly the one in Bandung city. A learning platform used was Zoom meeting. The T8 showed several pictures of the transportation and described the pictures. Then, T8 asked some questions about the types and uses of the transportation.

During the warming up session, T8 showed a video on the Indonesian transportation and asked some questions with regard to the video. The students payed attention to the pictures and answered the teacher's questions. The students were then requested to watch a short video and answered the teacher's questions based on the video. In addition, the other BIPA teachers (T2, T4, T5, \& $\mathrm{T} 7$ ) in different themes, they used the other different media to develop conceptual knowledge on the materials that would be taught through several themes, such as congklak, wayang (puppets), batik, blangkon, angklung, sports items, and pictures of daily habits (VirtInt-T2, T4, T5, \& T7). Since these activities were done remotely, therefore, teachers were reminded by Ofgang (2020) to personally engage with every student. By doing so, the students would be encouraged to interact with the teachers and the other students.

In the main activity, the teacher showed a short text to the students through sharing a screen on the Zoom meeting. The teacher read the text and highlighted several words showing the types of the transportation and explained the "adjectives" used in the text. The students were asked to read 
Table 1

Main Activities Implemented by BIPA Teachers in The Remote Learning

\begin{tabular}{|c|c|c|c|c|}
\hline School Level & Targeted Skills & Warming-up Session & Main Activities Done & $\begin{array}{c}\text { Evaluation } \\
\text { Session }\end{array}$ \\
\hline $\begin{array}{l}\text { - Primary } \\
\text { school } \\
\text { - Secondary } \\
\text { school }\end{array}$ & $\begin{array}{l}\text { - Reading, } \\
\text { - Writing, } \\
\text { - Listening, } \\
\text { - Speaking, } \\
\text { - Grammar } \\
\text { (developing } \\
\text { Indonesian } \\
\text { competence } \\
\text { \& Indonesian } \\
\text { cultural } \\
\text { competence) }\end{array}$ & $\begin{array}{l}\text { - Teachers show } \\
\text { a video on } \\
\text { Indonesian } \\
\text { transportation; } \\
\text { - Teachers show } \\
\text { congklak, wayang } \\
\text { (puppets), } \\
\text { batik, blangkon, } \\
\text { angklung, sports } \\
\text { items, and pictures } \\
\text { of daily habits; } \\
\text { - Teachers ask } \\
\text { questions related } \\
\text { to the video, } \\
\text { congklak, wayang } \\
\text { (puppets), } \\
\text { batik, blangkon, } \\
\text { angklung, sports } \\
\text { items, and pictures } \\
\text { of daily habits; } \\
\text { - Students watch } \\
\text { the video on } \\
\text { the Indonesian } \\
\text { transportation; } \\
\text { - Students watch } \\
\text { the congklak, } \\
\text { wayang (puppets), } \\
\text { batik, blangkon, } \\
\text { angklung, sports } \\
\text { items, and pictures } \\
\text { of daily habits; } \\
\text { - Students answer } \\
\text { the teachers' } \\
\text { questions }\end{array}$ & $\begin{array}{l}\text { - Reading texts with } \\
\text { regard to Indonesian } \\
\text { cultures in various } \\
\text { topics relevant with } \\
\text { the contexts; } \\
\text { - Writing sentences } \\
\text { using terminologies } \\
\text { that have been } \\
\text { learned; } \\
\text { - Writing short } \\
\text { paragraphs using } \\
\text { the grammatical } \\
\text { rules that have been } \\
\text { learned; } \\
\text { - Writing short texts } \\
\text { using the themes } \\
\text { and topics of their } \\
\text { interests; } \\
\text { - Listening to } \\
\text { teachers' stories; } \\
\text { - Listening to stories } \\
\text { through watching } \\
\text { videos relevant } \\
\text { to the contexts } \\
\text { and topics that } \\
\text { have been earlier } \\
\text { discussed; } \\
\text { - Answering } \\
\text { teachers'questions } \\
\text { orally; } \\
\text { - Retelling the } \\
\text { materials that have } \\
\text { been learned; } \\
\text { - Retelling other } \\
\text { stories relevant with } \\
\text { the contexts and } \\
\text { topics of their own } \\
\text { interests. }\end{array}$ & $\begin{array}{l}\text { - Students } \\
\text { practice } \\
\text { pronouncing } \\
\text { words (and } \\
\text { retell the } \\
\text { content of the } \\
\text { text for the } \\
\text { students in } \\
\text { higher level); } \\
\text { - The linguistic } \\
\text { aspects taught } \\
\text { to students are } \\
\text { descriptive } \\
\text { texts through } \\
\text { the use of } \\
\text { adjectives; } \\
\text { - The structures } \\
\text { emphasized } \\
\text { to students } \\
\text { are a subject, } \\
\text { a verb, and } \\
\text { an adjective, } \\
\text { and a subject, } \\
\text { a verb and an } \\
\text { adverb. }\end{array}$ \\
\hline
\end{tabular}

the short text and payed attention to the pronunciation of the words spoken by the teacher. The students repeated the teacher's pronunciation on the selected words and then they wrote the words in the table provided by the teacher informing the types of transportation and the adjectives used to explain the words. 
Finally, during the evaluation session, the students were encouraged to practice pronouncing the words and for the students in higher level, they were required to retell the content of the text. The linguistic aspects taught to the students including the descriptive text characterized by the uses of adjectives. The structures emphasized in the text covering a subject, a verb, and an adjective and a subject, a verb, and an adverb. The vocabulary introduced to the students was a public car called an "angkot". Form these descriptions, the teaching stages were identified to start from showing, modelling, practicing, exploring, to evaluating. Due to COVID-19 pandemic, these activites were done by $\mathrm{T} 8$ through a synchronous mode using one of the learning platforms called Zoom Meeting.

In addition to the Zoom Meeting implemented by T8, there were other learning platforms used by the BIPA teachers during the COVID-19 pandemic. The other learning platforms used by the BIPA teachers are presented in Table 2.

With regard to Table 2, in addition to the Zoom Meeting used by T8, there were some other learning platforms used by the other BIPA teachers. Google Classroom, for instance, was considered to be the most favorite learning platform used by $\mathrm{T} 1, \mathrm{~T} 4$, T6, T7, and T8. Then, it was followed by Microsoft Teams which was applied by T2, T3, T7, and T8. Cisco Webex was operated by $\mathrm{T} 1, \mathrm{~T} 2$, and $\mathrm{T} 8$ as the third most favorite learning platform. It was then followed by Kahoot and Education Perfect which were implemented by $\mathrm{T} 1$, T5 and T7, T8 consecutively. The other learning platforms were Indolingo (used by T3), Zoom Meeting (T8), Bamboozle, Gimkit, Quizlet, Quizizz, Stile, and Vocaroo (T5), and Compass Portal and Languages Online (T7).

Also, the BIPA teachers have to think of using relevant technologies applied during the learning process and providing the students with friendly tasks and home assignments using the defined relevant technologies (Ray, 2020a) for further practices and students' enrichment which are suitable with the individual students' conditions. Therefore, decisions on the use of ICT in the remote learning during the COVID-19 pandemic should be carefully

Table 2

Learning Platforms Used by BIPA Teachers

\begin{tabular}{ccl}
\hline No & Teacher (T) & \multicolumn{1}{c}{ Platforms Used by Teachers in Learning Activities } \\
\hline 1 & T1 & Cisco Webex, Google Classroom, Kahoot \\
2 & T2 & Cisco Webex, Microsoft Teams \\
3 & T3 & Indolingo, Microsoft Teams \\
4 & T4 & Google Classroom \\
5 & T5 & Bamboozle, Gimkit, Kahoot, Quizlet, Quizizz, Stile, Vocaroo \\
6 & T6 & Google Classroom \\
7 & T7 & Compass Portal, Education Perfect, Google Classroom, Languages \\
& & $\begin{array}{l}\text { Online, Microsoft Teams } \\
\text { Cisco Webex, Education Perfect, Google Classroom, Microsoft } \\
8\end{array}$ \\
& T8 & Teams, Zoom Meeting
\end{tabular}

Source: Quest (T1-T8) 
thought and coordinated (Ali, 2020) among the related parties. Table 3 shows the details of the learning objectives, students' required competences, themes delivered to students, stages of teachers' main activities, and the teaching aids (media) used to support the remote learning. The details of the implementation of remote learning experienced by the BIPA teachers in Victorian schools during the COVID-19 pandemic in the year 2020 are presented in Table 3.

Based on data presented in Table 3 above, there are two main objectives of learning Indonesian during the COVID-19 pandemic, i.e. developing Indonesian and cultural competences since language and cultures are interrelated one to another (Wurianto, 2015, p. 129). In the real teaching experiences, some descriptions were given to provide relevant information on the required competence for BIPA beginners. For instance, they were done through using basic expressions, creating simple question and answer sessions, and making simple spoken and written interactions (Adnyani et al., 2014).

The main activities applied by the BIPA teachers consisted of a modeling implemented through reading aloud, showing pictures, and explaining the materials. Then, the other three main activities were listening to students' individual reading practices, a discussion between teacher and students, and doing simple practices based on the materials that have been selected to be delivered to the students. Meanwhile, the students' required competences included identifying different

Table 3

Remote Learning Implemented by BIPA Teachers

\begin{tabular}{|c|c|c|c|c|}
\hline $\begin{array}{c}\text { Learning } \\
\text { Objectives }\end{array}$ & $\begin{array}{l}\text { Students' Required } \\
\text { Competences }\end{array}$ & $\begin{array}{l}\text { Themes } \\
\text { Delivered to } \\
\text { Students }\end{array}$ & $\begin{array}{c}\text { Stages of } \\
\text { Teachers' Main } \\
\text { Activities }\end{array}$ & $\begin{array}{l}\text { Teaching Aids } \\
\text { (Media) Used } \\
\text { to Support } \\
\text { Learning }\end{array}$ \\
\hline $\begin{array}{l}\text { Developing } \\
\text { Indonesian } \\
\text { competence; } \\
\text { Developing } \\
\text { Indonesian } \\
\text { cultural } \\
\text { competence. }\end{array}$ & $\begin{array}{l}\text { - Identifying some } \\
\text { terminologies } \\
\text { of Indonesian } \\
\text { concerning } \\
\text { relevant themes; } \\
\text { - Using some of } \\
\text { the terminologies } \\
\text { in the relevant } \\
\text { learning contexts; } \\
\text { - Identifying } \\
\text { different types } \\
\text { of Indonesian } \\
\text { cultures; } \\
\text { Describing types } \\
\text { of Indonesian } \\
\text { cultures; } \\
\text { Writing short } \\
\text { essays about } \\
\text { Indonesian } \\
\text { cultures }\end{array}$ & $\begin{array}{l}\text { - Indonesian } \\
\text { food; } \\
\text { - Indonesian } \\
\text { traditional } \\
\text { clothes; } \\
\text { - Indonesian } \\
\text { musical } \\
\text { instruments; } \\
\text { - Indonesian } \\
\text { daily life. }\end{array}$ & 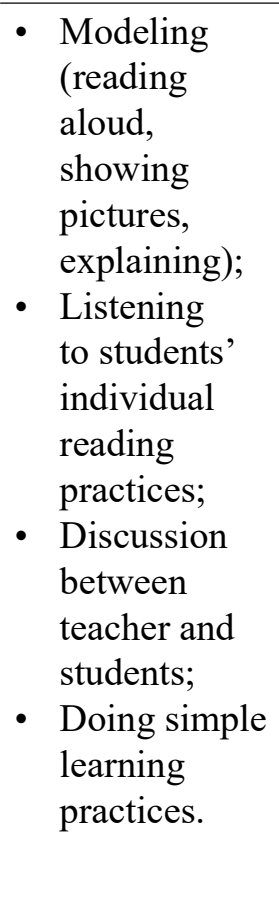 & $\begin{array}{ll}\text { - } & \text { congklak } \\
\text { - } & \text { wayang } \\
\text { - } & \text { buppets) } \\
\text { - } & \text { blangkon } \\
\text { - } & \text { angklung } \\
\text { - } & \text { gambar } \\
\text { kegiatan olah } \\
\text { raga (pictures } \\
\text { of sport } \\
\text { activities) } \\
\text { gambar } \\
\text { kegiatan } \\
\text { sehari-hari } \\
\text { (pictures } \\
\text { of daily } \\
\text { activities). }\end{array}$ \\
\hline
\end{tabular}


types of Indonesian cultures, mentioning types of the Indonesian cultures, describing types of the cultures, and writing short essays about the Indonesian cultures based on the topics that have been identified and determined by both the students and the teachers.

Three samples of teaching materials are described in the following sections to provide the students with some insights into the materials, media and cultural aspects for the BIPA classes during the COVID-19 pandemic. Based on the objectives, materials, main activities, required competences, and media used to support remote learning presented in Table 1 above, for further practical remote learning purposes, there were three samples of teaching practices organized by the local teachers together with the BIPA teachers to implement the teaching and learning programs. With regard to the required competences, for instance, Supriyadi $(2018$, p.44) reiterates the importance of prodiving descriptions of competence. These descriptions were meant to attract, encourage, and stimulate students' engagement in the learning activities. Three activities are presented here to provide relevant examples for the implementation of BIPA teaching practices based on the teachers' experiences. Three of the following examples were also meant to introduce vocabularies to the students. They were made based on the teachers' experiences in three different activities, namely: cooking a favorite Indonesian food 'Nasi Goreng', attracting students with fruit serving 'Pisang Goreng', and getting familiar with an 'angkot', a public transportation in Bandung. The challenges faced by BIPA teachers in remote learning are also discussed to provide the students with some information and descriptive experiences on how they were dealing with their problems and finding out their solutions.
The vocabulary knowledge in the implementation of remote learning could be done by picking up some terminologies to improve the students' vocabularies. In this particular context, the Cooking a Favorite Indonesian Food 'Nasi Goreng' was selected to be one of the themes to elaborate to provide students with one of the Indonesian foods, namely "nasi goreng" (fried rice). In response to the materials used by the teacher in the process of remote learning and referring to the process of virtual interview (Virt-Int) with one of the BIPA teachers (Teacher-4, T4), shared that the students were happy to study on how to cook Indonesian food. The high interest of students in cooking "nasi goreng" (fried rice) (Cambridge University Press, 2020), for instance, was positively responded by T4 through creating a video on the process of making the fried rice and sharing the video to the students. It was enthusiastically commented by the students and even by the parents showing their curiousity in the Indonesian food, particularly the fried rice. The activity of cooking done by T4 has positively given relevant experiences for both students and parents. This experience has given a chance for the parents to identify and recognize $\mathrm{T} 4$ through the video that has been created and shown to students and their parents. The words shared by $\mathrm{T} 4$ in the virtual interview (Virt-Int):
Mereka senang belajar tentang
makanan Indonesia. Salah satu
makanan yang mereka ketahui
adalah nasi goreng. Untuk itu, saya
berusaha membuat video tentang
cara membuat nasi goreng untuk
disampaikan kepada siswa dan
bahkan para orang tua. Pengalaman
ini sangat mengesankan sehingga
ketika bertemu dengan orang tua, mereka sudah bisa mengidentifikasi
bahwa sayalah orang yang 
membuat video itu. (They [students and parents] are happy to study about Indonesian food. One of the Indonesian foods they know is "nasi goreng" (fried rice). Therefore, I try to create a video on how to cook the fried rice and send it to students and even to parents. It is an impressing experience that on the occasion when I met the parents, they had already recognized me that I was the one who created the video (Virt-Int-T4).

In the implementation of remote learning, teachers were also required to creatively design the learning materials to be delivered to the students through relevant media to achieve success in students' learning. Based on the results of virtual interview (Virt-Int) with the Teacher-1 (T1), this difficult situation had directed T1 as a BIPA teacher to think very hard to make powerpoints for the virtual class presentation. In addition, to deal with native Australian, T1 was also requested to create some videos to support students' understanding on the materials being presented. One of the topics to be presented to the students was Penyajian Buah-buahan (Fruit Serving) and one of the fruits to elaborate was pisang (banana) as one of the most popular Indonesian fruits (Virt-Int-T1). It was then entitled Attracting Students with Fruit Serving 'Pisang Goreng'. Bananas were selected since they are popular in Indonesia and banana trees grew very well in different parts of Indonesia as a tropical country. As a result, bananas have their own varieties which automatically influenced ways on how to eat them. Some of them can be served and consumed directly but the other varieties should be cooked in different ways to meet the needs of people's taste and interests.
In oder to provide deeper understanding on serving the bananas, eight different types of bananas (Arthasalina, 2018) are identified to serve people with different taste, i.e. pisang cavendish, pisang susu (susu = milk), pisang raja (raja = king), pisang ambon (Ambon is a capital city of Maluku Province, eastern part of Indonesia), pisang kepok, pisang tanduk (tanduk $=$ horn), pisang nangka (nangka = jackfruit), and pisang mas ( mas = gold). Six banana varieties (Arthasalina, 2018) could be consumed without further cooking processes, such as pisang cavendish, pisang susu, pisang raja, pisang ambon, and pisang mas. Meanwhile, the other three varieties were pisang kepok and pisang tanduk which would be more delicious to be fried as pisang goreng (fried banana) particularly served with tea or coffee in the morning and late in the afternoon and pisang nangka which was better served as banana chips.

In addition to the learn typical specific vocabularies, the teaching and learning implementation process during the COVID-19 pandemic should also be approached differently by both teachers and students to achieve maximum results in the challenging and difficult times. The different approaches should consider the overall situations and conditions of students, teachers, facilities and technologies available to support the remote learning. These should be comprehensively understood by the relevant parties to decide the most applicable systems, facilities, and technologies to meet the overall learning objectives supported by the adequate learning materials that should be selected by the teachers to satisfy students and the main language learners, in this particular context is the BIPA students in Victorian schools, Australia.

During the remote learning process, Teacher-6 (T6) created Google slides with regard to a public transportation in Bandung 
city, Indonesia entitled "Getting Familiar with an Angkot, a Public Transportation in Bandung". In the city of flower, for instance, many students and office workers used public transportations to go to schools and offices. One of the public transportations is called "angkot" (angkutan kota, a small car functioning as a public transportation that can carry six to ten passangers operated in the city to take the passangers from one determined area to another). In the remote learning process, based on the result of virtual interview with the BIPA teacher (Virt-Int-T6), T6 tried to introduce the students to main vocabularies that should be mastered when traveling by public car, for instances, "kiri", "tujuh", "lima", and "payun".

The word "kiri", literally means "left", was used by passangers to inform the driver to stop the car upon the arrival at their destinations. Then, "tujuh" means "seven" refers to the maximum number of passangers who can sit on one side of the bench in the car. Meanwhile, "lima" (five) refers to the possible number of passangers who can sit on the other side of the bench in the public car. The words "tujuh" and "lima" were usually spoken by the driver or his co-driver in this order "tujuh-lima" to inform the passengers who were sitting in the car that the car could accommodate seven people on one side and five people on the other side. In addition, the words "tujuh-lima" were also verbally spoken by the driver or his assistant to the upcoming passangers that, in the driver or his assistant's consideration, they could be accommodated in the car. Finally, the word "payun" (a Sundanese, a local language spoken by native people of Bandung), literally means "front" (Athur, 2020) to give an instruction to the driver to stop the car in few metres after the word was spoken by any of the passangers instead of "kiri".
In compliance with the public transportation as it was shared by $\mathrm{T} 6$ during the virtual interview (Virt-Int), there was a similar topic exploring a direction experienced by T4 (Virt-Int-T4). Through the use of a Google map, T4 tried to introduce the students to different locations and directions on how to go to students' houses. Using a video recording due to COVID-19 pandemic to implement the remote learning, T4 introduced some important vocabularies to students, i.e. "kanan" (right), "kiri" (left), "belok kanan" (turn right), "belok kiri” (turn left), and "lurus" ([go] straight) (Cambridge University Press, 2020). In this particular context, the word "kiri" (left) (Virt-Int-T4), for instance, referred to a direction to find the position of a place, a house or an office which is different from that of "kiri" (left) in the context of T6 which referred to an instruction for a driver of a public car to stop the car to drop off the passangers.

In addition to success stories about the remote learning implemented by BIPA teachers during the COVID-19 pandemic, there were some problems that should be faced by the BIPA teachers to come up with some alternative solutions. Many activities organized in the classrooms held during the normal time, but they were difficult to be implemented during the COVID-19 pandemic done through online learning services. Teacher-2 (T2) admitted such conditions where once $\mathrm{T} 2$ faced a difficult time to manage the remote learning which was only followed by one student. In this situation, during a virtual interview (VirtInt), T2 shared the experience:

Masalah terbesar yang saya hadapi pada saat siswa harus belajar di rumah karena pandemi COVID-19 adalah kurangnya motivasi mereka. Pada saat kondisi normal motivasi belajar mereka terjaga, sedangkan 
pada masa pandemi, motivasi mereka menurun karena siswa menggunakan waktu jeda untuk istirahat (tidur) sehingga siswa malas untuk memulai kembali pelajaran berikutnya. (The biggest problem I faced when the students were supposed to study from home (SFH) due to COVID-19 pandemic was the decrease of their motivation. In the normal condition, their motivation to study was stable, but during the pandemic, their motivation decreased since the students used their time break to take a nap, as the consequence, they were lazy to restart the next lessons) (VirtInt-T2).

As it was experienced by T2, particularly in facing low-motivated students, remote learning has also been concerned by Murgatrotd (Ali, 2020) identifying the weaknesses of the remote learning with regard to teachers' concerns and learning conditions at home. Various working conditions of teachers and the students' learning conditions at home would also determine the success of remote learning and these conditions have to be taken into considerations by the relevant parties involved in the process of making decisions about the implementation of the remote learning.

In order to solve remote learning problems, local teachers and the BIPA teachers did regular meetings to discuss the lesson plans together to result in more applicable and acceptable plans by both students and teachers. The coordination between the local teachers and BIPA teachers was done to create the more appropriate learning materials, relevant games that would be applied to students during the week, and cultural contents that might be accommodated to the remote learning (Virt-Int-T7). One of the other cultural contents was about "tata krama" (manners) in which an Indonesian was pointing someone else using "jari jempol" (a thumb) to show a respect. Through this experience, the students were practicing on how to point someone else using their thumbs to practice showing their manners to respect other people in Indonesian contexts (Virt-Int-T7). The words spoken by Teacher-7 (T7) regarding the activity of collaborating with the local teachers to create the lesson plans:

Setiap hari Senin kami melakukan koordinasi untuk membuat perencanaan pengajaran untuk satu minggu ke depan. Kami membahas tentang materi, permainan, dan budaya yang bisa dimasukkan ke dalam pembelajaran. Misalnya, kita belajar tatakrama, bahwa orang Indonesia menunjuk untuk meminta orang lain melakukan sesuatu dengan menggunakan jari jempol. Kemudian para siswa mempraktikkan teori tata krama tersebut. Dengan praktek ini, para siswa mempraktekkan menunjuk seseorang dengan menggunakan jari jempol mereka sebagai praktek dari pelajaran tata krama yang mereka dapatkan dari kelas bahasa Indonesia tersebut. (Every Monday, we coordinate with the local teachers about lesson plans for a week. We discuss learning materials, games, and cultural contents that can be included in the learning materials. For instance, we are studying manners indicating that Indonesians point someone else to ask for a favour through using his or her thumb. The students are then practicing the theory of the manners. 
Through this practice, the students practice pointing somebody by using his or her thumb to practice the manners that have been learned from their Indonesian class (Virt-Int-T7).

The quotation [3] above indicated that during the COVID-19 pandemic, the local teachers and BIPA teachers always did collaboration to create the lesson plans which were applicable and acceptable by the related parties, such as students, teachers, and even parents who accompanied their daughters or sons to follow the Indonesian lessons. Three main aspects very carefully formulated by the local teachers and BIPA teachers were learning materials, games, and cultural contents (Virt-Int-T7). The learning materials were designed to meet the needs of learners and to achieve a certain language competence based on the students' particular level. The games were also made referring to the materials that have been formulated to provide the students with some fun activities to attact their interest to learn the Indonesian. The cultural contents were also specifically made to achieve students' cultural knowledge with regard to the the materials that have been earlier formulated to enrich the students' overall understanding on the target language cultures. Some of the Indonesian cultures introduced to students are presented in Table 4.

The elements of Indonesian cultures were introduced by the BIPA teachers to the students through integrating the cultural elements in the learning practices through their active engagement in online interactions. The introduction to the cultural elements aimed to build the students' knowledge on Indonesian cultures and develop true conceptual frameworks between Indonesian and Australian cultures. It was done through showing simple and clear examples to provide the students with better and easier understanding on the targeted cultures. The Indonesian cultural aspects introduced to students can be seen in Table 4 above. Cooking Indonesian food is one of the themes to introduce to them. The other themes explored in this particular

Table 4

Indonesian Cultural Aspects Introduced to Students

\begin{tabular}{ll}
\hline \multicolumn{1}{c}{ Theme } & \multicolumn{1}{c}{ Indonesian Cultural Aspects Introduced to Students } \\
\hline Cooking Indonesian & - Typical Indonesian food \\
food & - Cooking procedures \\
& - Habits or ways of eating bananas for Indonesians \\
& - Ways to serve the food \\
Indonesian & - Typical Indonesian transportation \\
transportation & - How to use the Indonesian transportation \\
Indonesian fruit & - Habits of Indonesians in public transportation \\
serving & - Typical Indonesian fruits \\
& - How to cook the Indonesian fruits \\
Manners & - How to serve the Indonesian fruits \\
& - Hays of pointing other people to show a respect \\
\hline
\end{tabular}

Source: Virt-Int \& Quest (T1-T8) \& Docs (OIER, 2011-2019). 
context could be made to show some differences of cultural elements. These can be viewed from types of their activities, serving strategies, table manners, and their daily habits and routines.

\section{CONCLUSION}

The COVID-19 pandemic has changed the BIPA teachers to implement the remote learning. It requires the BIPA teachers to prepare the classes through selecting different learning platforms applicable for both the teachers and the students. The fast change of learning system from offline to remote learning has directed the teachers to be more creative and innovative in designing their learning and made the use of technology without ignoring the main objective of learning that is to develop the students' language and cultural competences. The learning platforms selected by the BIPA teachers are depended on the learning materials that will be taught to students. The main learning activities are implemented by using clear learning stages from modelling, listening, discussing to practicing with the use of appropriate application media. The interaction that has been created in the learning activities is facilitated with different teaching aids and media that are interesting for the students. The unique teaching aids do not only help the teachers to improve the students' knowledge in terms of remembering, describing, and explaining the linguistic aspects of the Indonesian, but also develop their cultural knowledge about Indonesia.

\section{REFERENCES}

Adnyani, N. L. P. S., Paramarta, I. M. S., Sudana, P. A. P, Suparwa, I. N., \& Satyawati, M. S. (2014, November). Pengembangan bahan ajar BIPA kontekstual berbasis budaya lokal Bali. Paper presented at Seminar
Nasional Riset Inovatif II 2014. https://eproceeding.undiksha.ac.id/ index.php/senari/article/view/415.

Ali, W. (2020). Online and remote learning in higher education institutes: A necessity in light of COVID-19 pandemic. Higher Education Studies, 10(3), 1625. doi:10.5539/hes.v10n3p16.

Arthasalina, D. (2018, 27 May). Delapan jenis pisang dan cara mengolahnya yang benar, sudah tahu? IDN Times. https://www.idntimes.com.

Athur, M. S. (2020). Kamus bahasa daerah lengkap terjemahan Indonesia. www. kamusdaerah.com.

Cambridge Dictionary. (2020). Make your words meaningful. Cambridge University Press. https://dictionary. cambridge.org/.

Creswell, J. W. (2012). Educational research: Planning, conducting, and evaluating quantitative and qualitative research ( $4^{\text {th }}$ ed. $)$. Pearson.

Hancock, D. R., \& Algozzine, B. (2006). Doing case study research: A practical guide for beginning reseachers. Teachers College Press.

Hardini, T. I., Setyarini, S., \& Harto, S. (2019). Indonesian assistant program in Australian schools: Recruitment and selection process. Cakrawala Pendidikan, 38(2), 331-342. doi: 10.21831/cp.v38i2.25083.

Hartoyo. (2009). Penerapan model pembelajaran kontekstual berbasis kompetensi untuk meningkatkan efektivitas pembelajaran. Jurnal Kependidikan, 39(1), 67-78. https:// journal.uny.ac.id/index.php/jk/article/ view/233.

Hooker, C. (2020, 10 September). Strategies for assessing students remotely. https://www.techlearning.com/howto/strategies-for-assessing-studentsremotely. 
Istanti, W. (2020, July 23). Darmasiswa dan digitalisasi BIPA. Suaramerdeka. news. https://suaramerdeka.news/ darmasiswa-dan-digitalisasi-bipa/.

Majid, A. (2013). Strategi pembelajaran. PT. Remaja Rosdakarya.

Malik, R. S., \& Hamied, F. A. (2016). Research methods: A guide for first time researchers. UPI Press.

Mana, L. H. A., Yusandra, T. F., Atmazaki, \& Ramadhan, S. (2020). Pengembangan buku ajar keterampilan menyimak berbasis contextual teaching and learning. Jurnal Kependidikan, 4(1), 152-164. doi: https://doi.org/10.21831/jk.v4i1.

Memorandum of Understanding (MoU) between Universitas Pendidikan Indonesia (UPI), Monash University, Australia, and Department of Education and Training (DET), Victoria, Australia, 2004.

Memorandum of Understanding (MoU) between Universitas Pendidikan Indonesia (UPI), Monash University, Australia, and Department of Education and Early Childhood Development (DEECD), Victoria, Australia, 2010.

Memorandum of Understanding (MoU) between Universitas Pendidikan Indonesia (UPI) and Department of Education and Training (DET), Victoria, Australia, 2017.

Nielsen, L. (2020, 7 July). Effective online learning practices. https://www. techlearning.com/tl-advisor-blog/8.

OIER [Office of International Education and Relations] Universitas Pendidikan Indonesia. (2011-2019). Laporan guru bantu bahasa Indonesia bagi penutur asing (BIPA) Universitas Pendidikan Indonesia di Victoria, Australia. Unpublished Institutional Report.

Ofgang, E. (2020, 17 September). Remote vs. in-person classes: What the data shows. https://www.techlearning.com/ news/remote-vs-in-person-classeswhat-the-data-shows.

Ray, K. (2020a, 31 March). What is remote learning? https://www.techlearning. $\mathrm{com} /$ how-to/what-is-remote-learning.

Ray, K. (2020b, 4 April). How to make a remote learning lesson plan. https:// www.techlearning.com/how-to/howto-make-a-remote-learning-lessonplan.

Setyawan, A., Suwandi, S., \& Slamet, St. Y. (2017). Pengenalan budaya lokal dalam pengajaran bahasa Indonesia bagi penutur asing (BIPA) di Indonesia melalui materi teks eksplanasi. The $1^{\text {st }}$ Education and Language International Conference Proceedings Center for International Language Development of Unissula, 1(1), 118-124. http:// jurnal.unissula.ac.id/index.php/ELIC/ article/view/1218.

Sinha, A., \& Basu, D. (2020, May). Educational landscape during and after the Covid-19 pandemic: Strategies and adaptations to encourage quality teaching and learning. Paper presented at Agricultural Extension in South Asia. Rome, Beijing, New Delhi, Vientiane, and Sydney.

Supriyadi. (2018). Quality of bahasa Indonesia textbooks used in junior high school. Jurnal Kependidikan, 2(1), 39-55. doi: https://doi.org/10.21831/ jk.v2i1.10122.

UNESCO. (2020, 26 March). UNESCO rallies international organizations, civil society and private sector partners in a broad Coalition to ensure \#LearningNeverStops. https:// en.unesco.org/news/unesco-ralliesinternational-organizations-civilsociety-and-private-sector-partnersbroad.

Wurianto, A. B. (2015). Pembelajaran bahasa Indonesia bermuatan budaya 
sebagai penguatan masyarakat ekonomi ASEAN (MEA): Pengalaman di USSH Ho Chi Minh City. In Seminar Nasional Pendidikan Bahasa Indonesia Tahun 2015. https://publikasiilmiah. ums.ac.id/handle/11617/6368.

Yusari, N. I. (2012, December). Konsep privasi: Masalah lintas budaya dalam pengajaran bahasa Indonesia untuk penutur asing. Paper presented at Prosiding Seminar Internasional
Multikultural \& Globalisasi. Fakultas Ilmu Pengetahuan Budaya, Universitas Indonesia. https://www.researchgate. net/publication/323028478.

Zhang, W., Wang, Y., Yang, L., \& Wang, C. (2020). Suspending classes without stopping learning: China ${ }^{\text {ee }} \mathrm{s}$ education emergency management policy in the COVID-19 outbreak. Journal of Risk and Financial Management, 13(55), 1-6. doi:10.3390/jrfm13030055 